\title{
Cartilaginous Fusion
}

National Cancer Institute

\section{Source}

National Cancer Institute. Cartilaginous Fusion. NCI Thesaurus. Code C124504.

Joined together by cartilage. 